ANNA ŁOSOWSKA* - LUBLIN

\title{
DUCHOWNI WYŚWIECCENI W LUBLINIE PRZEZ BISKUPA PRZEMYSKIEGO MACIEJA DRZEWICKIEGO (28 II 1506)
}

Problematyka średniowiecznych święceń duchownych ma już pokaźną literaturę, mimo to, każde nowo odnalezione źródło poszerza naszą wiedzę nie tylko o prawach i obowiązkach tej zbiorowości, ale przybliża konkretne, dotąd najczęściej anonimowe, osoby. Edward Rittner, autor wydanego przed stu laty podręcznika, wymienił i scharakteryzował prawne wymogi oraz warunki, które winni spełniać zarówno przyjmujący, jak też udzielający święceń. W grupie okoliczności uniemożliwiających wejście do stanu duchownego znalazło się $\mathrm{m}$. in. nieprawe urodzenie, ułomność fizyczna bądź choroba uniemożliwiająca w przyszłości sprawowanie funkcji (defectus corporis), niedostateczny wiek i wykształcenie, brak tzw. łagodności chrześcijańskiej (defectus perfectae lenitatis), także brak niezawisłości (defectus libertatis) ${ }^{1}$.

Święcenie jako ważny, obok beneficjum, element stratyfikacji duchowieństwa omówił Antoni Gąsiorowski. Autor przypomniał podstawowy podział na święcenia niższe (ostiariat, lektorat, egzorcystat, akolitat) i wyższe (subdiakonat, diakonat, prezbiteriat), objaśnił kryteria objęcia beneficjum plebańskiego, procedurę udzielania święceń na poszczególne stopnie, wymagane odstępy czasowe pomiędzy nimi oraz terminy, w których można było dokonać święceń. Przeanalizował też najstarsze wykazy wyświęconych w diecezji kujawskiej²

Wykazy osób wyświęconych kryją w sobie bogactwo informacji. Przede wszystkim wymieniają konkretne liczby duchowieństwa szeregowego, często nieobecnego w badaniach grup kanonickich katedralnych i kolegiackich. Można wyczytać, z jakich kręgów się wywodzili, dokąd byli kierowani, aby pełnić Bożą służbę i kto odpowiadał za materialną stronę tej służby. Ważne jest to tym bardziej, że same święcenia nie zamykały się w granicach jednej diecezji. Mogły do nich przystąpić osoby pochodzące z różnych, nieraz bardzo odległych miejscowo-

*Anna Łosowska - dr historii, kierownik Archiwum Uniwersytetu Marii Curie-Skłodowskiej w Lublinie.

${ }^{1}$ E. Rittner, Prawo kościelne katolickie, Lwów 1912, s. 90 -110.

${ }^{2}$ A. Gąsiorowski, Święcenia w diecezji kujawskiej na przełomie XV i XVI wieku, „Roczniki Historyczne", 67 (2001) s. 79-104. 
ści, pod warunkiem posiadania odpowiedniej zgody od swojego biskupa. Wymóg ten, usankcjonowany w statutach biskupa Mikołaja Trąby, był niezbędny, potwierdzał bowiem, że kandydat do święceń jest dobrych obyczajów, odpowiedniego wieku, posiada wiedzę, jest prawego pochodzenia i posiada stałe kościelne beneficjum, patrymonium lub wystarczającą prowizję ${ }^{3}$.

$\mathrm{Na}$ źródłową wartość zachowanych wykazów wyświęcanych duchownych wskazywał ks. Jan Kracik ${ }^{4}$, a Eugeniusz Wiśniowski, na podstawie księgi święceń diecezji płockiej z lat 1514-1530, przechowywanej w Bibliotece Zakładu Narodowego im. Ossolińskich we Wrocławiu, przebadał liczebność duchowieństwa, warunki dochodzenia do święceń oraz miejsce duchownych w danym środowisku społecznym $^{5}$. Ta sama księga posłużyła Krzysztofowi Kaczmarkowi do opracowania zagadnienia święceń zakonników ${ }^{6}$.

Najwcześniejsze spisy osób przyjmujących święcenia kapłańskie zachowały się w księgach czynności biskupów poszczególnych diecezji. Na przykład istnienie takiego spisu, obejmującego jedenaście osób wyświęconych na akolitę w 1480 roku przez biskupa krakowskiego Jana Rzeszowskiego, sygnalizował Zdzisław Pietrzyk $^{7}$. Uwagę badaczy przyciągnęły też najwcześniejsze wykazy wyświęconych pochodzące z diecezji gnieźnieńskiej. Grupę około sześciuset osób, które przyjęły święcenia kapłańskie w latach 1482-1493 z rąk biskupa Zbigniewa Oleśnickiego, omówił Jacek Wiesiołowski ${ }^{8}$. Odrębne opracowanie poświęcone wyświęconym przez tegoż biskupa zakonnikom, przygotował też Krzysztof Kaczmarek $^{9}$.

Interesujące informacje odnalazł Andrzej Radzimiński w piętnastowiecznym rękopisie przechowywanym w bibliotece w Uppsali, znanym jako Formularius pro novellis notariis in curia dominorum Episcoporum. Jest to formularz dokumentów przeznaczony dla młodych notariuszy zatrudnianych na dworach biskupich $^{10}$. Większość zamieszczonych $\mathrm{w}$ formularzu dokumentów dotyczyło biskupstw pruskich: chełmińskiego, warmińskiego, sambijskiego oraz pomezań-

${ }^{3}$ J. Zubka, Tytut kanoniczny do święceń dla duchowieństwa świeckiego w szczególności stużby diecezji, Lublin 1935, s. 116-117.

4 J. Kracik, Księgi święceń i konsekracji jako źródto historyczne, „Notificationes e Curia Metropolitana Cracoviensi”, 119 (1981) s. 216-222.

${ }^{5}$ E. Wiśniowski, Liczebność duchowieństwa diecezjalnego na ziemiach polskich $w$ pierwszej połowie XVI wieku, „Roczniki Humanistyczne” (dalej: RH), 16 (1968) z. 2, s. 45-46; tenże, Duchowni święceni w roku 1515 w świetle płockiej księgi święceń, RH, 34 (1986) s. 507-512.

${ }^{6}$ K. Kaczmarek, Święcenia zakonników w diecezji płockiej w pierwszej połowie XVI wieku, „Roczniki Historyczne”, 77 (2012) s. 103-148.

${ }^{7}$ Księgi egzaminów do święceń $w$ diecezji krakowskiej z lat 1573-1614, oprac. Z. Pietrzyk, Kraków 1991, s. 26.

${ }^{8}$ J. Wiesiołowski, Środowiska kościelne i kultura, w: Kultura Polski średniowiecznej XIV-XV wieku, red. B. Geremek, Warszawa 1997, s. 256-307.

${ }^{9}$ K. Kaczmarek, Zakonnicy na wykazach święconych z księgi arcybiskupa gnieźnieńskiego Zbigniewa Oleśnickiego (1482-1493), w: Wielkopolska-Polska-Czechy. Studia z dziejów średniowiecza ofiarowane Profesorowi Bronistawowi Nowackiemu, Poznań 2009, s. 297-315.

${ }^{10}$ A. Radzimiński, Piętnastowieczny formularz z Uppsali jako źródto do badania dziejów kościoła w państwie Zakonu Krzyżackiego w Prusach, w: Aetas media aetas moderna. Studia ofiarowa- 
skiego. Wśród nich znalazły się dokumenty spraw związanych z udzielaniem święceń przez poszczególnych biskupów diecezjalnych. Ważną informacją jest na przykład, że w diecezji warmińskiej była prowadzona specjalna księga święceń już w 1400 roku. Wpisywano do niej informacje o przyjmowaniu święceń przez duchownych, o osobach, które polecały ich biskupom oraz prowizorach zapewniających im utrzymanie ${ }^{11}$.

Nowatorskie i kompleksowe opracowanie praskiej księgi wyświęconych z lat 1395-1416 przygotowała Eva Doležalová ${ }^{12}$. Z zamieszczonego przez Autorkę przeglądu badań wynika, że najstarsze spisy osób dopuszczonych do stanu duchownego zachowały się w Anglii, Francji i Hiszpanii (XIII-XV wiek) oraz w Czechach (święcenia praskie) ${ }^{13}$. Wszechstronne omówienie praskiej księgi wyświęconych zostało poprzedzone gruntownym studium tego specyficznego źródła. Przedstawiony został także sam rytuał udzielania święceń na poszczególne stopnie i wskazane atrybuty, które były niejako symbolem poszczególnej grupy kandydatów na duchownych ${ }^{14}$.

Bogatszą literaturę posiadają święcenia duchownych w drugiej połowie XVI wieku. Wykaz duchownych z księgi czynności biskupów kujawsko-pomorskich, przechowywanej w Archiwum Archidiecezjalnym we Włocławku, przygotował Witold Kujawski ${ }^{15}$. Więcej informacji znalazło się w edycjach wykazów osób wyświęconych w diecezjach krakowskiej i gnieźnieńskiej, przygotowanych przez Zdzisława Pietrzyka ${ }^{16}$. Z tego okresu pochodzą też informacje zebrane przez J. Jarošową o święceniach udzielonych przez Antonina Brusa arcybiskupa Pragi w latach 1561-1580 ${ }^{17}$. Wśród duchownych wyświęconych wówczas na różne stopnie znaleźli się także klerycy z diecezji krakowskiej (12), gnieźnieńskiej (4), płockiej (3), poznańskiej (6) i wrocławskiej (64) ${ }^{18}$.

ne profesorowi Henrykowi Samsonowiczowi w siedemdziesiąta rocznicę urodzin, Warszawa 2000, s. 231-246.

${ }^{11}$ Tamże, s. 238-239.

${ }^{12}$ E. Doležalová, Svěcenci pražské diecéze 1395-1416, Praha 2010.

${ }^{13}$ Wydał je A. Podlaha, Liber ordinationum cleri 1395-1416, Praha 1922. Autorka omawia też wcześniejsze wydawnictwo: Libri confirmationum ad beneficia ecclesiastica Pragensem per archidiocesim VIII-X (Praha 1889), przygotowane przez Josefa Emlera, w którym znalazły się podstawowe informacje o samych święceniach, jak też procedurze ich udzielania, E. Doležalová, Svěcenci pražské diecéze, s. 18.

${ }^{14}$ Rytuał zachował się w Liber Pontyfikale Albrechta ze Szternberku. Na przykład wyświęcany na stopień najniższy (ostiarius) otrzymywał symboliczne klucze od świątyni, lektorowi przekazywano księgę perykop, a egzorcyście-księgę z niezbędnymi dla odprawiania egzorcyzmów modlitwami, E. Doležalová, Svěcenci pražské diecéze, s. 43-47.

${ }^{15}$ W. Kujawski, Wykazy święconych z najstarszej księgi akt działalności biskupów włocławskich Kurozwęckiego i Przerębskiego - lata 1496-1511, „Archiwa, Biblioteki i Muzea Kościelne”, 72 (1999) s. 23-112; A. Gąsiorowski, Święcenia w diecezji kujawskiej na przełomie XVi XVI wieku, „Roczniki Historyczne”, 67 (2001) s. 79-105.

${ }^{16}$ Księga egzaminów do święceń w diecezji gnieźnieńskiej z lat 1563-1603, wstęp i oprac. Z. Pietrzyk, Kraków 2009; zob. też przypis 7.

${ }^{17}$ J. Jarošova, Knihy svěcenců obnoveného pražského arcibiskupstvi z druhé poloviny 16. století, „Sborník Národního Muzea v Praze”, 15 (1970).

${ }^{18}$ Tamże, s. 68-69. 
Nieznane, a interesujące wykazy wyświęconych z pierwszej połowy XVI wieku zachowały się w księdze biskupów przemyskich, Mikołaja Drzewickiego i Jana Karnkowskiego ${ }^{19}$. Są cenne tym bardziej, że w diecezji przemyskiej nie zachowały się odrębne księgi egzaminów do święceń, ani księgi szesnastowicznych wizytacji. Przechowywana w Archiwum Archidiecezjalnym w Przemyślu papierowa księga o sygnaturze 12, zinwentaryzowana jako Acta actorum consistorii episcopalis Premisliensis ex annis 1505-1529. Acta sive regestrum actorum causarum publicarum coram R.D. Joanne Karnkowski episcopo Premisliensis conscripta 1529-1536, jest w rzeczywistości księgą biskupią. Jej oryginalny tytuł, (...) Acta acticata coram Reverendissimo patre et domino Mathiam dei gratia episopo Premisliensis (...), została uzupełniona dopiskiem: Liber octavus episcopatus oraz rysunkiem księżyca w nowiu z wizerunkiem ludzkiej twarzy, umieszczonym w dolnej części pierwszej karty. Rysunek opatrzono słowami Luna perfecta ${ }^{20}$.

W księdze znajdują się wpisy z lat: 1505-1512 (czasy biskupa Macieja Drzewickiego), 1525 (biskup Andrzej Krzycki) oraz 1529 i 1531 (biskup Jan Karnkowski). Na ostatnich kartach księgi wpisano transumpty przywilejów niektórych parafii. Wpisy te wniesiono odpowiednio w latach 1531, 1533 i 1536, kiedy biskupa Jana nie było już w diecezji. Do księgi wniesiono też wykaz duchownych, którzy przyjęli święcenia w Lublinie, a więc w diecezji krakowskiej, z rąk Macieja Drzewickiego, biskupa przemyskiego. Źródło nie było znane ks. Jarosławowi Marczewskiemu, dlatego uznał, że nie zachowała się żadna informacja dotycząca uroczystości święcenia duchownych w późnośredniowiecznym Lublinie ${ }^{21}$.

Maciej Drzewicki, od 1505 roku biskup przemyski, przybył do Lublina na sejm walny, jako podkanclerzy Królestwa Polskiego ${ }^{22}$. Dotarł tu 11 stycznia, w przeddzień przyjazdu z Litwy króla Aleksandra. W sobotę, 28 lutego, w klasztorze ojców dominikanów udzielił święceń 73 osobom: 41 akolitom, 25 subdiakonom, 4 diakonom i 3 prezbiterom ${ }^{23}$. Takie uprawnienia, tak w stosunku do kandydatów, jak i miejsca, umożliwiła specjalna „licencja”, którą otrzymał od biskupa krakowskiego, Jana Konarskiego.

Przypadek udzielenia święceń przez „obcego” biskupa i na terenie obcej die-

${ }^{19}$ A. Łosowska, Wykazy wyświęconych $w$ diecezji przemyskiej w pierwszej połowie XVI wieku, w druku.

${ }^{20}$ Natomiast w księdze nr 10, utworzonej w 1927 roku przez ks. Jana Kwolka, archiwariusza przemyskiego, poprzez wydzielenie jej z oryginalnej księgi nr 7, znajduje się wizerunek słońca, także z obliczem ludzkim. Rysunek został opatrzony napisem Sol iusticiae i adnotacją poniżej Liber septimus, przy czym słowo septimus zostało nadpisane nad zamazanym słowem quartus.

${ }^{21}$ J.R. Marczewski, Duszpasterska działalność Kościoła w średniowiecznym Lublinie, Lublin 2002, s. 78.

${ }^{22}$ Sejm walny w Lublinie został zwołany na 6 stycznia i obradował do 18 marca 1506 roku. Akta Aleksandra (1501-1506), wyd. F. Papée, Kraków 1927, s. 508, nr 301; s. 529, nr 317.

${ }^{23}$ Archiwum Archidiecezjalne w Przemyślu (dalej: APP), Acta consistorii episcopalis Premisliensis ex annis 1505-1529 (dalej: ACC), nr 12, k. 19-21. Istnienie tego wykazu sygnalizował wydawca dziennika biskupa Macieja Drzewickiego, H. Rybus, Dwa źródta do biografii Macieja Drzewickiego, „Roczniki Teologiczno-Kanoniczne”, 3 (1957) z. 2. Niestety, niedokładnie zinterpretował zapis podając, że święcenia odbyły się w Krakowie, a dokonali tego biskupi: Maciej Drzewicki i Jan Konarski razem. 
cezji nie był niczym nadzwyczajnym. Jak wspomniano, prawo wyświęcania należało do ordynariusza, ale rozległość ówczesnych diecezji sprawiała, że nie przestrzegano tego przepisu. Kandydaci mogli przystąpić wszędzie pod warunkiem posiadania „pozwolenia”, co każdorazowo było opatrzone określeniem „de licentia sui diocesani”. Podobne „pozwolenie” otrzymywał też biskup, który udzielał święceń poza swoją diecezją, w tym przypadku Maciej Drzewicki, biskup przemyski, od Jana Konarskiego, biskupa krakowskiego. Można spekulować, dlaczego biskup Jan osobiście nie dopełnił obowiązku święceń, mimo, że był w Lublinie w czasie trwania obrad sejmowych. Być może było to spowodowane obowiązującymi terminami i biskup Konarski nie zdążył przybyć na czas, a może była to zwykła niedyspozycja w danym dniu (biskup cierpiał na podagre), dlatego przekazał swoje uprawnienia młodszemu o dwadzieścia lat koledze, w dodatku podkancerzemu Królestwa. W każdym razie 2 marca 1506 roku, kiedy przyjmowano tymczasową ustawę wojenną dla Małopolski i Rusi, byli obecni biskupi diecezji położonych na tych terenach: Jan Konarski, biskup krakowski, Bernard Wilczek, biskup lwowski, Maciej Drzewicki, biskup przemyski i Mikołaj Kościelecki, biskup chełmski ${ }^{24}$.

Według prawa kanonicznego święcenia duchownych powinny odbywać się w sześć sobót w roku, cztery w kwartalne suche dni (Quatuor Tempora) oraz w sobotę wielkanocną i sobotę po Podwyższeniu Krzyża. Terminy te, zapisane w dekretałach papieża Aleksandra III i powtórzone w traktacie Mikołaja z Błonia, przytoczył Antoni Gąsiorowski ${ }^{25}$. Obowiązywały we wszystkich diecezjach polskich, chociaż z czasem udzielano święceń akolitatu także w niedzielę. Zdarzyło się tak w Przemyślu, że w 1531 roku biskup Jan Karnkowski dwukrotnie święcił na stopień akolity właśnie w niedzielę.

W Lublinie ta podniosła uroczystość miała miejsce w sobotę, quattuor temporum post cinerum, czyli 28 lutego 1506 roku. Najwięcej, bo 41 osób przyjęło święcenia niższe, ale nie udało się ustalić, jak duża ich część przyjęła później święcenia wyższe. W literaturze uważa się, że spośród tej grupy wywodziła się największa część duchownych, którzy pełnili funkcje pomocnicze w parafiach. Według obliczeń Franciszka Stopniaka w połowie XVI wieku na terenie archidiakonatu lubelskiego pracowało 41 wikariuszy, którzy zajmowali się duszpasterstwem $^{26}$. Niestety, nie da się ustalić, czy wśród nich byli „nasi” akolici, chociaż niewątpliwie z nich rekrutowała się również grupa duchownych „wędrownych”. Badania przeprowadzone dla diecezji krakowskiej i dla okresu po reformie trydenckiej wskazują, że osoby, które nie uzyskały święceń wyższych zatrudniano w charakterze sług kościelnych, nauczycieli szkół parafialnych, organistów bądź kantorów ${ }^{27}$. Według Eugeniusza Wiśniowskiego, prowadzącego wieloletnie bada-

${ }^{24}$ Akta Aleksandra, nr 312, s. 525.

${ }^{25}[\ldots]$ sex tempora anni sunt deputati (...) ad conferendum ordines (...) Quatuor Temporibus singulis, sabbato Sicientes et sabbato Pasce. Gąsiorowski, Święcenia w diecezji kujawskiej, s. 81.

${ }^{26}$ F. Stopniak, Duchowni w parafiach archidiakonatu lubelskiego w okresie kontrreformacji, RH, 7 (1958) z. 2, s. 269.

${ }^{27}$ Księgi egzaminów do święceń $w$ diecezji krakowskiej z lat 1573-1614, oprac. Z. Pietrzyk, Kraków 1991, s. 9. 
nia nad klerem parafialnym, przyczyną ,włóczęgostwa” duchownych było poszukiwanie wyższych dochodów, bądź unikanie konsekwencji nadużyć, jakich mogli dopuścić się na obszarze własnej diecezji. I jakkolwiek każdy pleban, który przyjmował obcego duchownego, miał obowiązek sprawdzić jego pochodzenie i powód opuszczenia własnej diecezji, to w praktyce zdarzało się rzadko. A w przypadku rozległych terytorialnie parafii, gdy taki wikariusz był bardzo pożądany, niemożliwe ${ }^{28}$.

W połowie XVI wieku, w następstwie rozkwitu reformacji i ogólnego rozluźnienia dyscypliny w Kościele, dał się zauważyć duży niedobór duchowieństwa parafialnego. Szacunkowe liczby, obliczane według poszczególnych diecezji, przedstawił Stanisław Litak i ustalił, że pod względem liczebności kleru, najlepiej przezentowała się diecezja krakowska ${ }^{29}$.

Jak zatem rozkładała się struktura pochodzenia terytorialnego wyświęconych w Lublinie duchownych? Spośród 41 akolitów większość (34) pochodziła z rodzimej diecezji krakowskiej, pięć osób z diecezji poznańskiej i po jednej z diecezji chełmskiej i gnieźnieńskiej. Bardziej zróżnicowana terytorialnie była grupa subdiakonów. $Z$ diecezji krakowskiej znalazło się dziewięć osób, pięć z gnieźnieńskiej, cztery z przemyskiej, po trzy z chełmskiej i poznańskiej oraz jedna z płockiej. Święcenia diakonatu otrzymały tylko cztery osoby, w tym dwie z diecezji krakowskiej i po jednej z przemyskiej oraz wileńskiej. Trzech wyświęconych prezbiterów pochodziło z diecezji krakowskiej.

Tab. 1. Pochodzenie terytorialne wyświęconych

\begin{tabular}{|c|c|c|c|c|c|}
\hline Diecezja & Akolici & Subdiakoni & Diakoni & Prezbiterzy & Razem \\
\hline krakowska & 34 & 9 & 2 & 3 & 48 \\
\hline gnieźnieńska & 1 & 5 & & & 6 \\
\hline poznańska & 5 & 3 & & & 8 \\
\hline płocka & & 1 & & & 1 \\
\hline chełmska & 1 & 3 & & & 4 \\
\hline przemyska & & 4 & 1 & & 5 \\
\hline wileńska & & & 1 & & 1 \\
\hline Razem & 41 & 25 & 4 & 3 & 73 \\
\hline
\end{tabular}

Dane zebrane w tabeli jednoznacznie wskazują, że najwięcej osób przyjmujących święcenia w Lublinie pochodziło z diecezji krakowskiej. Po kilka osób odpowiednio z diecezji poznańskiej, gnieźnieńskiej, przemyskiej i chełmskiej oraz pojedyncze osoby z pozostałych diecezji. Jest zrozumiałe, że możliwość uzyskania święceń na miejscu, bez konieczności udawania się do stolicy diecezji, była zasadniczym powodem dla wielu miejscowych kandydatów. W przypadku osób z innych diecezji można przyjąć, że znaleźli się w Lublinie, bo tu obradował sejm, w którego obradach uczestniczyli biskupi, a to gwarantowało możliwość uzyska-

${ }^{28}$ E. Wiśniowski, Parafie $w$ średniowiecznej Polsce. Struktura i funkcje społeczne, Lublin 2004, s. 88-89.

${ }^{29}$ S. Litak, Parafie w Rzeczypospolitej w XVI-XVIII wieku, Lublin 2004, s. 126-135. 
nia święceń. Nie można też wykluczyć, że część kandydatów była już związana z dworami poszczególnych biskupów, pełniąc tam różnorodne funkcje.

W grupie wyświęconych przez biskupa Macieja Drzewickiego duchownych można ustalić kilka osób, które przyjęły święcenia na różne stopnie. Jakkolwiek Antoni Gąsiorowski przypomniał, że pomiędzy święceniami na poszczególne stopnie kapłańskie powinno upłynąc pięć lat ${ }^{30}$, to z biegiem czasu przestano zwracać uwagę na ten przepis. Na początku XVI wieku dokonywano święceń na kolejny stopień już po upływie kilku, czasem zaledwie dwóch tygodni, jeżeli akurat tak układał się kalendarz czynności biskupa. Wykaz osób, dla których „święcenia lubelskie" były tylko jednym z etapów, przedstawia tabela.

Tab. 2. Duchowni wyświęceni na więcej niż jeden stopień

\begin{tabular}{|c|c|c|c|c|}
\hline Wyświęcony & Akolitat & Subdiakonat & Diakonat & Prezbiteriat \\
\hline Michał ze Strzeszkowic s. Macieja & $?$ & $\begin{array}{c}20 \text { XII } 1505 \\
\text { Brzozów }\end{array}$ & $\begin{array}{l}28 \text { II } 1506 \\
\text { Lublin }\end{array}$ & $\begin{array}{l}11 \text { IV } 1506 \\
\text { Przemyśl }\end{array}$ \\
\hline Mikołaj z Krosna, s. Marcina & $?$ & jw. & jw. & jw. \\
\hline Andrzej z Przeworska s. Jakuba & $\begin{array}{l}20 \text { XII } 1505 \\
\text { Brzozów }\end{array}$ & $\begin{array}{l}28 \text { II } 1506 \\
\text { Lublin }\end{array}$ & $\begin{array}{l}28 \text { III } 1506 \\
\text { Radymno }\end{array}$ & $\begin{array}{l}11 \text { IV } 1506 \\
\text { Przemyśl }\end{array}$ \\
\hline Jan z Turobina s. Jana & $?$ & $\begin{array}{l}28 \text { II } 1506 \\
\text { Lublin }\end{array}$ & $\begin{array}{l}28 \text { III } 1506 \\
\text { Radymno }\end{array}$ & $\begin{array}{l}11 \text { IV } 1506 \\
\text { Przemyśl }\end{array}$ \\
\hline Mikołaj z Łochowa s. Michała & $?$ & jw. & jw. & jw. \\
\hline Marek z Jażyńca s. Macieja & $?$ & jw. & jw. & jw. \\
\hline Maciej z Sierakowic s. Macieja & $?$ & jw. & jw. & jw. \\
\hline Jerzy z Sosnowicy s. Stanisława & $?$ & jw. & jw. & jw. \\
\hline $\begin{array}{l}\text { Mikołaj z Pszczonowa s. Bartło- } \\
\text { mieja }\end{array}$ & $?$ & jw. & jw. & jw. \\
\hline Szymon z Sulikowa s. Stanisława & $?$ & jw. & jw. & jw. \\
\hline Jakub z Bzowa s. Wojciecha & $?$ & jw. & jw. & jw. \\
\hline Mikołaj z Inowłodza s. Jana & $?$ & jw. & jw. & jw. \\
\hline Łazarz z Jaślikowa s. Mikołaja & $?$ & jw. & jw. & jw. \\
\hline Mikołaj z Przytyku s. Mikołaja & $?$ & jw. & jw. & jw. \\
\hline Bernard z Pierśni s. Bartłomieja & $?$ & jw. & jw. & jw. \\
\hline Wacław z Rymanowa s. Grzegorza & $?$ & jw. & jw. & jw. \\
\hline Maciej z Woli Piasecznej s. Piotra & $\begin{array}{l}28 \text { II } 1506 \\
\text { Lublin }\end{array}$ & $\begin{array}{l}28 \text { III } 1506 \\
\text { Radymno }\end{array}$ & $\begin{array}{l}\text { 11 IV } 1506 \\
\text { Przemyśl }\end{array}$ & $?$ \\
\hline Jan ze Starołęki s. Wawrzyńca & jw. & jw. & jw. & $?$ \\
\hline
\end{tabular}

Zwraca uwagę, że wśród wyświęconych na wyższe niż akolitat stopnie znalazło się tylko dwóch kleryków z diecezji krakowskiej. Byli to Michał Socha ze Strzeszkowic, który otrzymał prowizję na parafię w Niżankowicach (diecezja przemyska) oraz Mikołaj z Przytyku, któremu utrzymanie gwarantował właściciel wsi Potok (diecezja krakowska).

\footnotetext{
${ }^{30}$ Gąsiorowski, Święcenia w diecezji kujawskiej, s. 80.
} 
W grupie kandydatów do święceń znalazło się siedmiu zakonników. Spośród nich święcenia akolitatu otrzymało dwóch dominikanów lubelskich (Maciej i Mikołaj) i jeden benedyktyn z Sieciechowa (Stanisław). Na stopień subdiakona wyświęcono brata Grzegorza z Przemyśla, bernardyna, być może z klasztoru przeworskiego, a na diakona - brata Jakuba, bernardyna ,de Lithvania”, zapewne z Wilna. Do święceń kapłańskich przystąpił Szymon, franciszkanin pochodzący z Wilkowa oraz Marcin z lubelskiego klasztoru dominikanów. Nie jest to grupa na tyle reprezentatywna, aby na jej podstawie formułować wnioski ogólne. Wszyscy wymienieni zakonni kandydaci do święceń przedstawili licentiam sui superioris (prioris), co oznaczało, że dana wspólnota zakonna bierze odpowiedzialność za swojego współbrata i zapewnia mu środki utrzymania. Niestety, nie odnaleziono tekstów takich pozwoleń.

Jednym z podstawowych warunków uzyskania święceń było zapewnienie materialnych środków do życia, czyli przedstawienie tytułu do święceń. Tylko niektórzy dysponowali własnymi majątkami, zapewniającymi bezpieczną egzystencję (super sufficiens patrimonium). Większość duchownych korzystała z systemu beneficjalnego i starała się o prowizję. Wydaje się, że nie wymagano obowiązku przedstawienia tytułu jedynie od kandydatów do święceń na stopień akolity. W wykazach święceń lubelskich nie odnaleziono żadnych adnotacji przy osobach starających się o to święcenie, a podobne zjawisko zauważył Antoni Gąsiorowski w odniesieniu do wyświęconych w diecezji kujawskiej ${ }^{31}$.

W przypadku starań o święcenia wyższe przy każdej osobie zaznaczano, z jakiego tytułu będą pochodzić środki na utrzymanie. Pojawiają się więc certa beneficia, czyli nazwy poszczególnych parafii, zobowiązania konkretnych osób i urzędów: kościelnych (kapituły katedralne i kolegiackie) lub świeckich (np. rady miejskie). Określano to wówczas terminem ad provisionem. Z reguły te same prowizje obowiązywały przy święceniach na kolejne, wyższe stopnie i takie zwyczaje można odnaleźć we wszystkich zachowanych wykazach święconych w diecezjach polskich końca XV i połowy XVI wieku.

Prawo prezenty duchownego na beneficjum wynikało z prawa patronatu. Przysługiwało fundatorowi i jego sukcesorom względem utworzonego beneficjum, na które składało się uposażenie oraz staranie o budynki i wyposażenie świątyni. Kandydata na określone beneficjum przedstawiano biskupowi, administratorowi sede vaccante lub wikariuszowi in spiritualibus, jak często miało to miejsce w Przemyślu, kiedy biskupa nie było w diecezji po kilka lat ${ }^{32}$.

Każdy patron mógł prezentować jednego lub kilku kandydatów równocześnie, jednakże z zachowaniem wyznaczonych terminów. Był to okres czterech miesięcy od dnia zawiadomienia patrona o wakansie. Jeżeli nie dokonano w tym

${ }^{31}$ Gąsiorowski, Święcenia w diecezji kujawskiej, s. 91; Doležalová, Svěcenci pražské diecéze, s. 119.

${ }^{32}$ Dobrze widać to na przykładzie, przechowywanej w Archiwum Archidiecezjalnym w Przemyślu, księgi nr 10, zatytułowanej Acta actorum consistorii episcopalis Premislienisis ex annis 1508-1520, która w rzeczywistości jest księgą wikariuszy in spiritualibus (Stefana Łochowskiego i Tomasza z Grodziska) oraz Mikołaja Błażejowskiego, vicesgerensa ówczesnego administratora diecezji, Mikołaja Rokosza. 
czasie prezenty wówczas beneficjum stawało się liberae collationis ${ }^{33}$.

Bogumił Szady zauważył, że przedmiotem prawa patronatu w potocznym jego znaczeniu były beneficja kościelne, w tym również kościoły, kaplice i fundacje, które nie miały charakteru właściwego beneficjum, ale posiadały obsadę duszpasterską, np. wikariaty i mansjonarie ${ }^{34}$. $Z$ takim przypadkiem spotykamy się w Przemyślu (Wincenty z Przemyśla, Grzegorz z Przemyśla). Autor wyodrębnił kategorie prawa patronatu beneficjów ze względu na wykonawcę i jakkolwiek jest to podział umowny to, warto się nad nim zatrzymać. Na czele pozostaje patronat biskupi (w odniesieniu do diecezji, w której położone było beneficjum). Na drugim miejscu wyodrębnono patronat kapitulny (wobec prałatur i kanonii swego kolegium), w kolejności królewski (wykonywany także przez starostów), mieszczański (burmistrzowie, wójtowie, rada miejska, cechy, bractwa i pojedynczy mieszczanie), akademicki, urzędniczy świecki i duchowny ${ }^{35}$. W tych kategoriach mieszczą się też prowizje duchownych wyświęconych w Lublinie. Ich wykaz, z wyłączeniem osób zakonnych, przedstawiono w tabeli. W rubryce „data święcenia”, podano także datę oraz stopień w przypadku osób, które uzyskały określone święcenia w diecezji przemyskiej.

Tab. 3. Wykaz prowizji

\begin{tabular}{|c|c|c|c|c|}
\hline Wyświęcony & $\begin{array}{l}\text { Prowizorzy du- } \\
\text { chowni }\end{array}$ & $\begin{array}{c}\text { Prowizorzy } \\
\text { świeccy }\end{array}$ & $\begin{array}{l}\text { Beneficjum pa- } \\
\text { rafialne }\end{array}$ & $\begin{array}{c}\text { Data } \\
\text { święcenia }\end{array}$ \\
\hline $\begin{array}{c}\text { Michał } \\
\text { ze Strzeszkowic }\end{array}$ & & & $\begin{array}{c}\text { Niżankowice } \\
\text { (diec. przemyska) }\end{array}$ & $\begin{array}{l}20 \text { XII } 1505 \text { (s) } \\
\mathbf{2 8} \text { II } \mathbf{1 5 0 6} \text { (d) } \\
11 \text { IV } 1506 \text { (p) }\end{array}$ \\
\hline $\begin{array}{c}\text { Stanisław } \\
\text { ze Szczekocin }\end{array}$ & & & $\begin{array}{c}\text { Garbów (diec. } \\
\text { krakowska) }\end{array}$ & 28 II 1506 (p) \\
\hline $\begin{array}{l}\text { Mikołaj } \\
\text { z Krosna }\end{array}$ & $\begin{array}{l}\text { Stefan Łochow- } \\
\text { ski, kanonik } \\
\text { skalbmierski }^{\mathrm{a}}\end{array}$ & & & $\begin{array}{l}20 \text { XII } 1505 \text { (s) } \\
\mathbf{2 8} \text { II } 1506 \text { (d) } \\
11 \text { IV } 1506 \text { (p) }\end{array}$ \\
\hline
\end{tabular}

${ }^{33}$ G. Wojciechowski, Prezenta, w: Encyklopedia katolicka, t. 16, Lublin 2012, kol. 394. Por. Wiśniowski, Parafie, s. 167-174.

${ }^{34}$ B. Szady, Prawo patronatu w Rzeczypospolitej w czasach nowożytnych, Lublin 2003, s. 26.

${ }^{35}$ Tamże, s. 33.

${ }^{a}$ Stefan z Łochowa był kanonikiem skalbmierskim i przemyskim, a od 1504 r. notariuszem w kancelarii biskupa Macieja Drzewickiego. Pochodził z wielkopolskiej rodziny Bylinów i w Gnieźnie uzyskał admisję notarialną. W Przemyślu był też wikariuszem in spiritualibus i oficjałem generalnym. Wraz z biskupem Drzewickim przeszedł do diecezji włocławskiej i był tam kanonikiem, wikariuszem in spiritualibus, oficjałem generalnym oraz proboszczem w Brześciu Kujawskim, A. Łosowska, Pennae investivi Praemisliae. Notariusze kancelarii kościelnych, pisarze sądów oraz urzędów świeckich w XV i na początku XVI wieku, Przemyśl 2011, s. 287-288. 


\begin{tabular}{|c|c|c|c|}
\hline $\begin{array}{c}\text { Andrzej } \\
\text { z Przeworska }\end{array}$ & $\begin{array}{l}\text { Rafał z Jarosła- } \\
\text { wia, kasztelan } \\
\text { przemyski }^{\text {b }}\end{array}$ & & $\begin{array}{c}20 \text { XII } 1505 \text { (a) } \\
\mathbf{2 8} \text { II } 1506 \text { (s) } \\
28 \text { III } 1506 \text { (d) } \\
11 \text { IV } 1506 \text { (p) }\end{array}$ \\
\hline $\begin{array}{c}\text { Jan } \\
\text { ze Starołęki }\end{array}$ & Jan Wrzosowskic & & $\begin{array}{c}20 \text { XII } 1505 \text { (a) } \\
\mathbf{2 8} \text { II } \mathbf{1 5 0 6} \text { (s) } \\
28 \text { III } 1506 \text { (d) }\end{array}$ \\
\hline Jan z Turobina & $\begin{array}{l}\text { Wincenty Świdwa } \\
\text { z Szamotul }{ }^{\mathrm{d}}\end{array}$ & & $\begin{array}{l}28 \text { II } 1506 \text { (s) } \\
28 \text { III } 1506(d) \\
11 \text { IV } 1506(p)\end{array}$ \\
\hline $\begin{array}{c}\text { Mikołaj } \\
\text { z Inowłodza } \\
\text { s. Jana } \\
\end{array}$ & $\begin{array}{l}\text { Adam Drzewicki, } \\
\text { starosta łukowski }^{\mathrm{e}}\end{array}$ & & $\begin{array}{l}28 \text { II } 1506 \text { (s) } \\
28 \text { III } 1506(d) \\
11 \text { IV } 1506(p)\end{array}$ \\
\hline $\begin{array}{l}\text { Mikołaj } \\
\text { z Łochowa }\end{array}$ & & $\begin{array}{l}\text { Inowłódz (diec. } \\
\text { gnieźnieńska) }\end{array}$ & $\begin{array}{l}28 \text { II } 1506 \text { (s) } \\
28 \text { III } 1506(d) \\
11 \text { IV } 1506(p)\end{array}$ \\
\hline Marek z Jażyńca & $\begin{array}{c}\text { Paweł z Wrzesz- } \\
\text { czowa }\end{array}$ & & $\begin{array}{l}28 \text { II } 1506 \text { (s) } \\
28 \text { III } 1506 \text { (d) } \\
11 \text { IV } 1506 \text { (p) }\end{array}$ \\
\hline $\begin{array}{c}\text { Jerzy } \\
\text { z Sosnowicy }\end{array}$ & & $\begin{array}{l}\text { Luboml (diec. } \\
\text { chełmska) }\end{array}$ & $\begin{array}{l}28 \text { II } 1506 \text { (s) } \\
28 \text { III } 1506 \text { (d) } \\
11 \text { IV } 1506 \text { (p) }\end{array}$ \\
\hline $\begin{array}{c}\text { Wacław } \\
\text { z Rymanowa }\end{array}$ & $\begin{array}{l}\text { Andrzej z Sadu- } \\
\text { rek, rajca lubel- } \\
\text { ski }^{f}\end{array}$ & & $\begin{array}{l}28 \text { II } 1506 \text { (s) } \\
28 \text { III } 1506(d) \\
11 \text { IV } 1506(\mathrm{p})\end{array}$ \\
\hline
\end{tabular}

${ }^{\mathrm{b}}$ Rafał z Jarosławia, kasztelan przemyski (1501-1507), Urzędnicy województwa ruskiego XIVXVIII wieku. Spisy, oprac. K. Przyboś, Wrocław 1987, s. 201, nr 1664. Był żonaty z Barbarą z Bnina, córką wojewody poznańskiego i starosty generalnego wielkopolskiego, Macieja, W. Dworzaczek: Leliwici Tarnowscy, Warszawa 1971, s. 255.

c Jan Wrzosowski z Wrzosowa, herbu Strzemię. Po zamążpójściu córki dobra wrzosowskie trafiły jako jej wiano w ręce Pieniążków, Herbarz Polski Kaspra Niesieckiego, t. 9, Lipsk 1842, s. 447.

${ }^{\mathrm{d}}$ Wincenty z Szamotuł Świdwa h. Nałęcz, starosta krasnostawski (1516-1525), kasztelan gnieźnieński(1518-1525). Zmarł w 1528 r., Urzędnicy województwa betskiego i ziemi chetmskiej XIV-XV wieku. Spisy, oprac. H. Gmiterek, R. Szczygieł, Kórnik 1992, s. 209, nr 1577. Świdwowie Szamotulscy byli właścicielami Turobina przez cały XV wiek, dopiero na początku XVI wieku, w następstwie małżeństwa Katarzyny Świdwówny z Łukaszem Górką, włość przeszła w ręce Górków, R. Tokarczyk, Turobin. Dzieje miejscowości, Lublin 2002, s. 61-76. O interesach Szamotulskich na Rusi także Z. Górczak, Ekspansja majątkowa rodziny Szamotulskich herbu Nałęcz na ziemiach ruskich w XV i poczatkach XVI wieku, w : Czechy-Polska-Wielkopolska. Studia z dziejów średniowiecza ofiarowane Profesorowi Bronisławowi Nowackiemu, red. Z. Górczak, J. Jaskulski, Poznań 2009, s. 317-329.

e Adam z Drzewicy, brat biskupa Macieja Drzewickiego, dotąd był wymieniany tylko jako rzekomy starosta łukowski w 1504 roku, Urzędnicy województwa lubelskiego XVI-XVIII wieku. Spisy, oprac. W. Kłaczewski, W. Urban, Kórnik 1991, s. 83, nr 606.

${ }^{\mathrm{f}}$ Andrzej z Sadurek, rajca i burmistrz lubelski od 1509 roku, M. Stankowa, Kancelaria miasta Lublina XIV-XVIII w., Lublin 1968, s. 97 


\begin{tabular}{|c|c|c|c|}
\hline Bernard z Pierśni & & $\begin{array}{l}\text { Kazimierz z Tu- } \\
\text { chowicza? (de } \\
\text { Tchuchowiecz) }\end{array}$ & $\begin{array}{l}28 \text { II } 1506 \text { (s) } \\
28 \text { III } 1506(d) \\
11 \text { IV } 1506(p)\end{array}$ \\
\hline $\begin{array}{c}\text { Maciej } \\
\text { z Sierakowic }\end{array}$ & & $\begin{array}{c}\text { Piotr Szafraniec, } \\
\text { kasztelan wiślicki } \\
\text { i starosta radom- } \\
\text { ski }^{\mathrm{g}}\end{array}$ & $\begin{array}{c}28 \text { II } 1506 \text { (s) } \\
28 \text { III } 1506(d) \\
11 \text { IV } 1506(p)\end{array}$ \\
\hline $\begin{array}{l}\text { Łazarz z Jaśliko- } \\
\text { wa }\end{array}$ & $\begin{array}{l}\text { Jan Latalski, } \\
\text { prepozyt krakow- } \\
\text { ski i gnieźnieński }\end{array}$ & & $\begin{array}{l}28 \text { II } 1506 \text { (s) } \\
28 \text { III } 1506(d) \\
11 \text { IV } 1506(p)\end{array}$ \\
\hline $\begin{array}{c}\text { Stanisław } \\
\text { z Pacanowa }\end{array}$ & $\begin{array}{l}\text { pleban w Wiel- } \\
\text { kim Rudnie (?) }\end{array}$ & $\begin{array}{l}\text { dziedzic wsi } \\
\text { Pruszyn(?) }\end{array}$ & 28 II 1506 (s) \\
\hline $\begin{array}{c}\text { Mikołaj } \\
\text { z Przytyku }\end{array}$ & & $\begin{array}{c}\text { Jakub Chamiec, } \\
\text { dziedzic wsi } \\
\text { Potok }^{\mathrm{j}} \\
\end{array}$ & $\begin{array}{l}28 \text { II } 1506 \text { (s) } \\
28 \text { III } 1506(\mathrm{~d}) \\
11 \text { IV } 1506(\mathrm{p})\end{array}$ \\
\hline $\begin{array}{c}\text { Maciej } \\
\text { z Piasecznej Woli }\end{array}$ & & $\begin{array}{l}\text { Stanisław, An- } \\
\text { drzej i Maciej } \\
\text { Smogorzewscy }\end{array}$ & $\begin{array}{l}\mathbf{2 8} \text { II } \mathbf{1 5 0 6} \text { (a) } \\
28 \text { III } 1506(\mathrm{~s}) \\
11 \text { IV } 1506(d) \\
\end{array}$ \\
\hline Jakub z Bzowa & $\begin{array}{l}\text { Bernard Wilczek, } \\
\text { arcybiskup } \\
\text { lwowskik }^{\mathrm{k}}\end{array}$ & & $\begin{array}{l}28 \text { II } 1506 \text { (s) } \\
28 \text { III } 1506(d) \\
11 \text { IV } 1506(p)\end{array}$ \\
\hline
\end{tabular}

g Piotr Szafraniec z Pieskowej Skały, miecznik krakowski, kasztelan wiślicki (1501-1507), starosta radomski (1494 -1507). Zmarł 30 IV 1508, Urzędnicy województwa sandomierskiego XVIXVIII wieku. Spisy, oprac. K. Chłapowski, A. Falniowska-Gradowska, Kórnik 1993, s. 149, nr 1202.

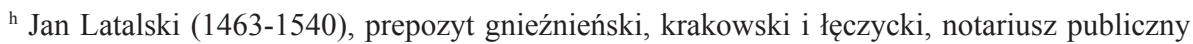
w konsystorzu poznańskim, kanclerz królowej Elżbiety Rakuszanki. Biskup krakowski, przeniesiony po śmierci Andrzeja Krzyckiego na arcybiskupstwo gnieźnieńskie, M.R. Górniak, B. Przybyszewski: Latalski Jan, w: Encyklopedia katolicka, t. 10, Lublin 2004, kol. 526-527.

${ }^{i}$ Nie wymieniono imienia ani plebana z Wielkiego Rudna ani dziedzica Pruszyna, jednak według ustaleń Jacka Chachaja plebanem w Rudnie od 1487 roku był Bernard Pruszyński, syn Mikołaja z Pruszyna, dziedzica Rudna i zapewne rodowego Pruszyna, J. Chachaj, Bliżej schizmatyków niż Krakowa...Archidiakonat lubelski w XVI wieku, Lublin 2012, s. 386.

jJakub Chamiec h. Gryf, dziedzic Potoku, w 1539 roku zabezpieczał posag żonie Jadwidze z Ostrowskich, Boniecki, t. 2, Warszawa 1900, s. 340. Być może jego synem był Wojciech Chamiec, pleban w Potoku, który w 1596 roku udzielił prowizji na wikariat w tymże Potoku Bartłomiejowi Tutce z Zawichostu, Księgi egzaminów, s. 139, nr 1092.

${ }^{\mathrm{k}}$ Bernard Wilczek herbu Poraj, arcybiskup lwowski w latach 1505-1540. Wcześniej był dziekanem kapituły katedralnej i oficjałem generalnym, a od 1498 roku także administratorem diecezji przemyskiej, J. Krętosz, Organizacja archidiecezji lwowskiej obrządku łacińskiego od XII wieku do 1772 roku, Lublin 1986, s. 69; A. Łosowska, Kolekcja Liber legum i jej miejsce w kulturze umystowej późnośredniowiecznego Przemyśla, Warszawa 2007, s. 52-53. 


\begin{tabular}{|c|c|c|c|c|}
\hline $\begin{array}{c}\text { Szymon } \\
\text { z Sulikowa }\end{array}$ & & Feliks Ożarowski ${ }^{1}$ & & $\begin{array}{l}28 \text { II } 1506 \text { (s) } \\
28 \text { III } 1506(d) \\
11 \text { IV } 1506(p)\end{array}$ \\
\hline $\begin{array}{c}\text { Szymon } \\
\text { z Kańczugi }\end{array}$ & & $\begin{array}{l}\text { Mikołaj z Pilczy, } \\
\text { starosta krasno- } \\
\text { stawski }^{\mathrm{m}}\end{array}$ & & $\begin{array}{c}28 \text { II } 1506 \text { (s) } \\
28 \text { III } 1506 \text { (d) } \\
6 \text { VI } 1506(\mathrm{p})\end{array}$ \\
\hline Jakub z Sanoka & $\begin{array}{l}\text { kapituła katedral- } \\
\text { na lwowska }\end{array}$ & & & $\begin{array}{c}28 \text { II } 1506(s) \\
28 \text { III } 1506(d) \\
6 \text { VI } 1506(p)\end{array}$ \\
\hline Jan z Trembowli & & & $\begin{array}{c}\text { Błożew (diec. } \\
\text { przemyska) }\end{array}$ & $\begin{array}{c}28 \text { II } 1506 \text { (s) } \\
28 \text { III } 1506 \text { (d) } \\
6 \text { VI } 1506 \text { (p) }\end{array}$ \\
\hline $\begin{array}{c}\text { Mikołaj } \\
\text { z Pszczonowa }\end{array}$ & & $\begin{array}{c}\text { Jan Bochotnicki } \\
\text { z Oleśnicy }\end{array}$ & & $\begin{array}{l}28 \text { II } 1506 \text { (s) } \\
28 \text { III } 1506(d) \\
11 \text { IV } 1506(p)\end{array}$ \\
\hline $\begin{array}{c}\text { Bartłomiej z Woli } \\
\text { Rakowskiej }\end{array}$ & $\begin{array}{c}\text { Maciej, pleban } \\
\text { lubelski }^{\circ}\end{array}$ & & & 28 II 1506 (s) \\
\hline $\begin{array}{c}\text { Mikołaj } \\
\text { z Poniatowej }\end{array}$ & & Piotr z Kijan ${ }^{\mathrm{p}}$ & & 28 II 1506 (s) \\
\hline $\begin{array}{c}\text { Mikołaj } \\
\text { z Łukowa }\end{array}$ & $\begin{array}{c}\text { Mikołaj, kanonik } \\
\text { lwowski }\end{array}$ & $\begin{array}{c}\text { Stanisław } \\
\text { z Kazanowa } \\
\end{array}$ & & 28 II 1506 (s) \\
\hline $\begin{array}{c}\text { Mikołaj } \\
\text { z Nasielska }\end{array}$ & & $\begin{array}{c}\text { Adam ze Zbuczy- } \\
\text { na z matką Anną }\end{array}$ & & 28 II 1506 (s) \\
\hline Piotr z Kielczy? & $\begin{array}{c}\text { Mikołaj, kanonik, } \\
\text { biskup elekt } \\
\text { chełmski }^{\text {s }}\end{array}$ & & & 28 II 1506 (s) \\
\hline
\end{tabular}

${ }^{1}$ Feliks Ożarowski z Ożarowa i Rudna h. Rawicz. Być może tożsamy z Felicjanem Ożarowskim późniejszym ksztelanem sanockim, S. Uhruski, Rodzina. Herbarz szlachty polskiej, t. 13, Warszawa 1916, s. 138.

${ }^{\mathrm{m}}$ Mikołaj Pilecki z Pilczy, starosta krasnostawski od 1503 roku, kasztelan wiślicki, a po 1511 roku wojewoda bełski, Urzędnicy województwa bełskiego, s. 208, nr 1575. Więcej na temat rodziny Pileckich, A. Wac, Kilka uwag o działalności gospodarczej panów z Pilicy w XIV-XVI wieku, „Annales Academiae Paedagogicae Cracoviensis", Studia Historica III, Kraków 2004, s. 475-484.

${ }^{n}$ Jan z Bochotnicy Oleśnicki, kasztelan małogojski (1506-1512), kasztelan wiślicki (15151519). Zmarł w 1532 r., F. Sikora, Oleśnicki Jan h. Dębno, w: Polski Słownik Biograficzny (dalej: PSB), t. 23 Wrocław 1976, s. 766-767.

${ }^{\circ} \mathrm{Z}$ dużym prawdopodobieństwem można przyjąć, że był to Maciej z Odolina, pleban i oficjał lubelski, a po rezygnacji z oficjalatu - pleban w Borowie, P. Hemperek, Oficjalat okregowy w Lublinie XV-XVIII w., Lublin 1974, s. 216.

${ }^{\mathrm{p}}$ Szlachetny Piotr z Kijan występował w 1506 r. jako komornik lubelski, Słownik historycznogeograficzny województwa lubelskiego w średniowieczu, oprac. S. Kuraś, Warszawa 1983, s. 100.

${ }^{r}$ Stanisław z Kazanowa Litwos, podkomorzy lubelski (1504-1524), podsędek sandomierski (1505-1517), referendarz koronny, A. Łosowska, Pennae, s. 284, przypis 472.

${ }^{s}$ Mikołaj Kościelecki, biskup chełmski (14 XI 1505- 4 V 1518), w: Encyklopedia katolicka, t. 3, Lublin 1985, kol. 132. 


\begin{tabular}{|c|c|c|c|}
\hline $\begin{array}{c}\text { Maciej z Wielkie- } \\
\text { go Opatowa }\end{array}$ & $\begin{array}{c}\text { Wojciech Jarocki, } \\
\text { pleban i oficjał } \\
\text { lubelski }^{\mathrm{t}}\end{array}$ & patrymonium & 28 II 1506 (s) \\
\hline Jakub z Wiślicy & $\begin{array}{c}\text { Jan, opat klaszto- } \\
\text { ru świętokrzy- } \\
\text { skiego }^{u}\end{array}$ & & 28 II 1506 (s) \\
\hline $\begin{array}{c}\text { Mikołaj } \\
\text { z Biskupic }\end{array}$ & & $\begin{array}{l}\text { Stanisław Kuro- } \\
\text { patwa, kasztelan } \\
\text { chełmskiw }^{\text {w }}\end{array}$ & 28 II 1506 (s) \\
\hline $\begin{array}{c}\text { Dominik } \\
\text { z Korytnicy }\end{array}$ & & $\begin{array}{c}\text { Jan Krupka, dzie- } \\
\text { dzic Korytnicy }\end{array}$ & 28 II 1506 (s) \\
\hline $\begin{array}{c}\text { Mikołaj } \\
\text { z Przytyku }\end{array}$ & & $\begin{array}{c}\text { Jan Chamiec, } \\
\text { dziedzic Potoku }\end{array}$ & 28 II 1506 (s) \\
\hline
\end{tabular}

Z powyższego zestawienia wynika, że wśród wyświęconych w Lublinie przeważał patronat świecki. Eugeniusz Wiśniowski wyliczył, że na początku XVI wieku w diecezji gnieźnieńskiej udział patronatu świeckiego wynosił 75,62\%, a w północnej części diecezji krakowskiej (Lubelszczyzna) aż 98,21\% ${ }^{36}$. W analizowanej grupie 34 duchownych wyświęconych na wyższe stopnie aż 19 osób otrzymało prowizje od rodów magnackich i szlacheckich oraz osób zajmujących wysokie stanowiska urzędowe (kasztelan, starosta). Jednym ze świeckich prowizorów był również lubelski burmistrz, a dwa razy prowizja miała charakter mieszany. Wśród prowizorów duchownych byli także kanonicy i prałaci oraz kapituła lwowska.

Wymagania stawiane kandydatom do kapłaństwa początkowo nie były wielkie i obejmowały znajomość siedmiu sakramentów, Składu apostolskiego, modlitw odmawianych w godzinach kanonicznych oraz rozumienia i umiejętności odprawiania mszy świętej. Z czasem wymagania zwiększyły się i u progu XVI wieku poziom wiedzy duchowieństwa stawał się przedmiotem troski ordynariuszy. Na przykład w Przemyślu, na zwołanym w 1511 roku przez biskupa Macieja Drzewickiego synodzie, postanowiono, że kandydaci do święceń mają obowiązek

${ }^{t}$ Mógł być oficjałem lubelskim po przejściu Piotra Bełżeckiego na prepozyturę szpitala św. Ducha w Lublinie. Brak akt oficjalatu lubelskiego z lat 1497-1506 uniemożliwiło poszukiwania i dlatego nie znalazł go P. Hemperek. Prawdopodobnie tożsamy z Wojciechem Jaroskim, plebanem lubelskim wymienionym w 1509 roku. Chachaj, Bliżej schizmatyków niż Krakowa, s. 353.

" Niewątpliwie był to Jan z Szydłowa, magister sztuk i rektor Uniwersytetu Krakowskiego (1475-1478) oraz rektor szkoły katedralnej na Wawelu (1478-1482). Po wstąpieniu do benedyktynów świętokrzyskich zasilił bibliotekę klasztorną własnymi kodeksami. W latach 1505-1509 pełnił funkcję opata, potem zrezygnował na rzecz Pawła ze Strzegomia, M. Derwich: W kręgu łysogórskiego opactwa benedyktynów, Kielce 2006, s. 132.

w Stanisław Kuropatwa z Łańcuchowa, syn Jana, był kasztelanem chełmskim w latach 14961520, Stownik historyczno-geograficzny, s. 135.

x Jakub Chamiec h. Gryf, dziedzic Potoku, w 1539 roku zabezpieczał posag żonie Jadwidze z Ostrowskich, Boniecki, t. 2, Warszawa 1900, s. 340. 
uczyć się w szkole katedralnej przynajmniej przez rok, a następnie odbyć praktykę w parafii ${ }^{37}$.W diecezji krakowskiej biskup Jan Konarski polecał patronom kościołów, aby prezentowali na stanowiska plebanów tylko takich kandydatów, którzy studiowali przez jakiś czas teologię lub prawo kanoniczne. Synod prowincjonalny zwołany do Łęczycy przez arcybiskupa Jana Łaskiego w 1523 roku rozszerzył to zalecenie na wszystkie diecezje metropolii gnieźnieńskiej i określił czas trwania studiów na trzy lata. W przypadku niespełnienia tego warunku kandydat na beneficjum był zobowiązywany do przynajmniej dwuletnich studiów już po instytucji na plebanię ${ }^{38}$.

Generalnie jednak nie można potwierdzić zależności między podjęciem studiów a święceniami. Przeważnie podejmowano naukę w młodszym wieku, zanim decydowano się na drogę duchowną. Przeciętny czas trwania studiów, niezbędny do zrealizowania pełnego programu nauczania w przypadku poziomu bakalaureatu, wynosił dwa lata. Starania o magisterium wymagały kolejnych trzech lat nauki. Do tego dochodził obowiązek uczęszczania, przynajmniej przez pół roku, na dysputy mistrzów, co odpowiednio wydłużało studia ${ }^{39}$. W takiej sytuacji znaczna część studentów przerywała naukę już po pierwszym semestrze.

Spośród duchownych wyświęconych przez biskupa Macieja Drzewickiego w Lublinie tylko nieliczni podjęli studia uniwersyteckie w Krakowie. Grupa dwudziestu trzech osób, które, z dużym prawdopodobieństwem, można odnaleźć w metrykach uniwersyteckich, to około $13 \%$ wszystkich wyświęconych. Nie jest to grupa liczna, ale można przyjąć, że reprezentatywna, albowiem podobną procentowo grupę można odnaleźć wśród wyświęconych przez Krzesława Kurozwęckiego w diecezji kujawskiej ${ }^{40}$. Wykaz osób, dla których potwierdzono studia uniwersyteckie zebrano w tabeli.

Tab. 4. Wykaz wyświęconych, dla których potwierdzono studia uniwersyteckie

\begin{tabular}{|c|c|c|c|c|}
\hline Lp. & Wyświęcony & Wykształcenie & Źródło & $\begin{array}{c}\text { Data/ stopień świę- } \\
\text { cenia }\end{array}$ \\
\hline 1. & $\begin{array}{c}\text { Jan z Turobina s. } \\
\text { Jana }\end{array}$ & $\begin{array}{c}\text { 1486-wpis w poczet } \\
\text { studentów, 1489- } \\
\text { bakałarz }\end{array}$ & $\begin{array}{c}\text { Księga promocji*, } \\
\text { s. 251, [1489/43] }\end{array}$ & $\begin{array}{l}28 \text { II } 1506(\mathrm{~s}) \\
28 \text { III } 1506(\mathrm{~d}) \\
11 \text { IV } 1506(\mathrm{p})\end{array}$ \\
\hline 2. & $\begin{array}{c}\text { Jakub z Lublina s. } \\
\text { Jana }\end{array}$ & $\begin{array}{l}\text { 1487-wpis, } 1500- \\
\text { bakałarz }\end{array}$ & $\begin{array}{l}\text { Ksiega promocji, } \\
\text { s. } 264[1500 / 41]\end{array}$ & 28 II 1506 (a) \\
\hline 3. & Jan z Lublina s. Jana & $\begin{array}{l}\text { 1506-wpis, } 1508- \\
\text { bakałarz }\end{array}$ & $\begin{array}{c}\text { Ksiega promocji, } \\
\text { s. } 275[1508 / 40)\end{array}$ & 28 II 1506 (a) \\
\hline 4. & $\begin{array}{l}\text { Wacław z Rymanowa } \\
\text { s. Grzegorza }\end{array}$ & $\begin{array}{l}\text { 1500- wpis w poczet } \\
\text { studentów }\end{array}$ & $\begin{array}{c}\text { Metryka Uniwersyte- } \\
\text { tu**, s. } 573 \\
{[1500 \mathrm{~h} / 447]}\end{array}$ & $\begin{array}{l}28 \text { II } 1506(\mathrm{~s}) \\
28 \text { III } 1506(\mathrm{~d}) \\
11 \text { IV } 1506(\mathrm{p})\end{array}$ \\
\hline
\end{tabular}

${ }^{38}$ Wiśniowski, Parafie, s. 159-160.

${ }^{39}$ K. Boroda, Studenci Uniwersytetu Krakowskiego w późnym średniowieczu, Kraków 2010, s.148-149.

${ }^{40}$ Gąsiorowski, Święcenia w diecezji kujawskiej, s. 97. 


\begin{tabular}{|c|c|c|c|c|}
\hline 5. & $\begin{array}{c}\text { Mikołaj z Inowłodza } \\
\text { s. Jana }\end{array}$ & $\begin{array}{c}\text { 1500-wpis, } 1506- \\
\text { bakałarz }\end{array}$ & $\begin{array}{r}\text { Ksiegga promocji, } \\
\text { s. } 272[1506 / 31]\end{array}$ & $\begin{array}{l}28 \text { II } 1506(\mathrm{~s}) \\
28 \text { III } 1506(\mathrm{~d}) \\
11 \text { IV } 1506(\mathrm{p})\end{array}$ \\
\hline 6. & $\begin{array}{c}\text { Mikołaj } \\
\text { z Krosna s. Marcina }\end{array}$ & 1504-bakałarz & $\begin{array}{l}\text { Ksiegga promocji, } \\
\text { s. } 270[1504 / 58]\end{array}$ & $\begin{array}{c}20 \text { XII } 1505 \text { (s) } \\
28 \text { II } 1506 \text { (d) } \\
11 \text { IV } 1506(\mathrm{p})\end{array}$ \\
\hline 7. & $\begin{array}{l}\text { Maciej z Wielkiego } \\
\text { Opatowa s. Marcina }\end{array}$ & $\begin{array}{c}\text { 1517-wpis, } 1519- \\
\text { bakałarz }\end{array}$ & $\begin{array}{l}\text { Ksiega promocji, } \\
\text { s. } 285[1519 / 40]\end{array}$ & 28 II 1506 (s) \\
\hline
\end{tabular}

* Najstarsza Ksiega promocji Wydziału Sztuk Uniwersytetu Krakowskiego z lat 1402-1541, wyd. A. Gąsiorowski, T. Jurek, I. Skierska, Warszawa 2011.

** Metryka Uniwersytetu Krakowskiego z lat 1400-1508, wyd. A. Gąsiorowski, T. Jurek, I. Skierska przy współpracy R. Grzesika, Kraków 2004.

*** Metryka czyli album Uniwersytetu Krakowskiego z lat 1509-1551, wyd. A. Gąsiorowski, T. Jurek, I. Skierska przy współpracy R. Grzesika, Warszawa 2010.

Porównanie danych z tabeli wskazuje, że święcenia wyższe z reguły następowały już po ukończeniu studiów. Była to jednak niewielka stosunkowo grupa, dlatego trudno uznać te wnioski za reprezentatywne. Nie wiadomo, jak było w przypadku święceń niższych, ale w Przemyślu z grupy siedemnastu osób, dla których potwierdzono studia, aż trzynastu kleryków przyjęło święcenia akolitatu zanim wpisało się w poczet studentów. Czy było to zjawisko charakterystyczne tylko dla diecezji przemyskiej, czy była to norma ogólnopolska, trudno jednoznacznie odpowiedzieć z powodu braku odpowiednich materiałów porównawczych.

Przedstawiony wykaz wyświęconych w Lublinie przez biskupa przemyskiego jest ważny z kilku powodów:

1. Źródło, które potwierdza wejście do stanu duchownego sporej grupy osób zamieszkujących obrzeża diecezji krakowskiej, zostało przedstawione po raz pierwszy.

2. Wykaz zachował się w księgach biskupów przemyskich, co oznacza, że w podobnych materiałach mogą znajdować się różne informacje wykraczajace poza granice jednej diecezji.

3. Potwierdzono, że procedura udzielania święceń oraz czynności przygotowujące kleryków do tej uroczystości były typowe dla wszystkich diecezji bez względu na położenie terytorialne.

4. W archidiakonacie lubelskim, w dziedzinie udzielania prowizji przeważał patronat świecki, reprezentowany głównie przez miejscowe rody szlacheckie

5. Zamieszczone wykazy wyświęconych, wśród których znaleźli się duchowni z innych diecezji, stanowić mogą materiał porównawczy do badań nad rozmieszczeniem niższego duchowieństwa w skali kraju. 


\begin{abstract}
ANEKS
Zamieszczony niżej spis wyświęconych przez biskupa Macieja Drzewickiego w Lublinie przedstawiono w wersji źródłowej, zachowując myśl i sposób zapisu notariusza. Wynika z niego, że wpisano wyświęconych na poszczególne stopnie, zaczynając od stopnia prezbitera. Akolici zostali wpisani jako ostatni. Przyjęta forma przekazu powoduje, że niektóre informacje z zamieszczonego wykazu powtórzą się, albowiem wcześniej zostały wykorzystane w części analitycznej tekstu (np. wykaz udzielonych prowizji, wykształcenie). W przypadku konkretnych osób, dla których udało się odnaleźć informacje i potwierdzić ich losy, zastosowano system odsyłaczy.

Archiwum Archidiecezjalne w Przemyślu, Acta actorum consistorii episcopalis Premisliensis ex annis 1505-1529. Acta sive regestrum actorum causarum publicarum coram R.D. Joanne Karnkowski episcopo Premisliensis conscripta 1529-1536, nr 12
\end{abstract}

\title{
k. 19
}

Anno Domini Millessimo quingentessimo sexto, Sabbato, quattuor temporum post cinerum in Lublin, per Venerabilem dominum Dominum Mathiam episcopum Premisliensem et Regiae Poloniae vicecancelarium de licentia Reverendissimum in Christo Patris et dominum Dominum Joannis eadem gratia episcopi Cracoviensis. In Ecclesia Conventuali Fratrum Ordinis Predicatorum intra muros Lublinensis promoti ad sacro ordines

\section{et primo ad gradum presbiteratus}

Stanislaus Stanislai de Szczekoczyn Cracoviensis dioecesis de licencia sui diocesani ad certum titulum ecclesie sue parochialis in Garbow ${ }^{41}$

Frater Simon de Wylkowo ordinis sancti Francisci fratrum minorum de observancia de licencia sui superioris

Frater Martinus de monasterio Lublynensis ordinis fratrum predicatorum de licencia sui superioris

\section{Ad gradum diaconatus}

Michael Mathiae de Strzeszkowycze Cracoviensis dioecesis ad certum titulum ecclesie sue parochialis in Nyezankowicze ${ }^{42}$

Frater Jacobus de Lithvania ordinis fratrum sancti Francisci fratrum minorum de observancia de licencia sui superioris

Nicolaus Martini de Crosna ${ }^{43}$ Premisliensis dioecesis ad provisionem venerabilis domini Stephani Lochowski canonici Scarbymyriensis

Frater Joannes de monasterio Lublynensis ordinis predicatorum de licencia sui superioris k. $19 \mathrm{v}$

${ }^{41}$ Był plebanem w Garbowie w latach 1506-1508. Chachaj, Bliżej schizmatyków niż Krakowa, s. 323. 16 marca 1508 roku przekazywał dziesiecinę snopową ze wsi Ługów na rzecz Jana Ożarowskiego, kanonika chełmskiego i kapelana króla Zygmunta, Archiwum Archidiecezjalne w Lublinie (dalej: AAL), Acta consistorii foranei Lublinensis (dalej: ACL), sygn. Rep 60 A 7, k. 22v.

${ }^{42}$ Michał ze Strzeszkowic Socha pozostawał na plebanii w Niżankowicach (diec. przemyska) co najmniej do 1519 roku, AAP, AAC, nr 11, k. 41.

${ }^{43}$ Występował jako kapelan biskupa Macieja Drzewickiego, kiedy poświadczał przekazanie przez Stanisława Szczekockiego dziesięciny na rzecz Jana Ożarowskiego. 


\section{Ad gradum subdiaconatus}

Joannes Joannis de Turobyn ${ }^{44}$ Chelmensis dioecesis de licencia sui ordinarii et ad provisionem generosi Vincentii Szwydwa de Samothuly

Venceslaus Gregory de Rymanowo ${ }^{45}$ Przemysliensis dioecesis ad provisionem generosi domini Andree de Sadurky consulem Lublynensem

Bartholomeus Gregory de Rapkowszkawola Posnanensis dioecesis de licencia sui ordinarii ad provisionem venerabilis domini Mathiae plebanum Lublinensem

Nicolaus Stanislai de Ponyathowa Cracoviensis dioecesis ad provisionem domini Petri Kyansky

Marcus Mathiae de Jaszyenicze ${ }^{46}$ Posnanensis dioecesis de licencia sui ordinarii ad provisionem venerabilis domini plebani Pauli in Wrzeszczow

Nicolaus Michaelis de Lochow ${ }^{47}$ Gnesnensis dioecesis de licencia sui ordinarii ad provisionem sue ecclesiae parochialis Inowlodz

Nicolaus Bartholomei de Lukow Cracoviensis dioecesis ad provisionem venerabilis et generosi dominorum Nicolai canonici Leopolyensis et Stanislai succamerarii Lublynensis de Kazanow heredum

Andreas Jacobi de Przeworszko dioecesis Premisliensis ad provisionem magnificii Raphaelis de Jaroslaw castellani Przemyszlyensis

Mathias Mathiae de Szyrakowycze Gnesnensis dioecesis ad provisionem magnifici domini

Petri Schafranyecz castellanum Vislyczensis et capitaneum Radomyensem de licencia sui ordinarii

Nicolaus Pauli de Naszylsk Plocensis dioecesis ad provisionem generosi Ade de Zabyczyn unacum matre sua Anna ${ }^{48}$

k. 20

Petrus Gregory de Kelszycza Cracoviensis dioecesis ad provisionem Reverendi domini Nicolai ecclesiae electi Chelmensem de licencia sui ordinarii

Bernardus Bartholomei de Pyerszna Gnesnensis dioecesis ad provisionem domini Casimir de Tchuchowyecz de licencia sui ordinarii ${ }^{49}$

Georgius Stanislai de Sosnowicza Chelmensis dioecesis ad certum titulum ecclesiae sui parochialis in Lubomlya de licencia sui ordinarii

Nicolaus Bartholomei de Pczyonow Gnesnensis dioecesis de licencia sui ordinari ad pro-

${ }^{44}$ Jan z Turobina s. Jana w jeszcze w latach 30-tych XVI wieku był audytorem kurii biskupiej w Przemyślu, AAP, AAC, nr 6, s. 487.

${ }^{45}$ Wacław z Rymanowa był w latach 1514-1518 mansjonarzem w kaplicy zamkowej w Lublinie, Chachaj, Bliżej schizmatyków niż Krakowa, s. 364.

${ }^{46}$ Dziś Jażyniec w diecezji poznańskiej.

${ }^{47}$ Mikołaj Bylina z Łochowa, s. Michała, był bratem Stefana Łochowskiego, notariusza publicznego, kanonika skalbmierskiego i przemyskiego, wikariusza in spiritualibus i oficjała generalnego przemyskiego. Na opuszczoną przez niego plebanię w Inowłodzu otrzymał prowizję właśnie Mikołaj. Był czasem mylony z Mikołajem z Inowłodza, synem Jana. Łosowska, Pennae, s. 80, przypis 67.

${ }^{48}$ Mikołaj z Nasielska był plebanem w Zbuczynie jeszcze w 1512 roku. Wówczas Adam ze Zbuczyna poświadczał ustanowienie pełnomocnictwa przez Macieja, kanonika chełmskiego dla Nikodema, prokuratora oficjała lubelskiego, AAL, ACL, sygn. Rep 60 A 7, k. 38.

${ }^{49}$ Nie zidentyfikowano osoby i miejscowości udzielającego prowizji Bernardowi z Pierśni. 
visionem generosi domini Joannis Bochothnyczky de Olesznycza capitaneum Chelmensem

Simon Stanislai de Sobykow Posnanensis dioecesis de licencia sui ordinarii ad provisionem domini Ozarowsky

Mathias Martini de Magna Opathow Cracoviensis dioecesis de licencia sui diocesani ad sufficiens patrimonium et ad provisionem venerabilis domini Alberti Jaroczki plebanis et officialis Lublinensis ${ }^{50}$

Jacobus Alberti de Bzow Przemisliensis dioecesis ad provisionem Reverendissimi in Christo patris et domini Bernardini archiepiscopi Leopoliensis

Nicolaus Joannis de Inowlodz ${ }^{51}$ Gnesnensis dioecesis de licencia sui ordinarii ad provisionem domini generosi Ade Drzewyczki capitaneum Lucoviensem

Jacobus Nicolai de Wislycza Cracoviensis dioecesis de licencia sui ordinarii ad provisionem venerabilis et religiosorum magistri Joannis abbatis sui quae Conventum Sancte Crucis in Calvo Monte

Lazarus Nicolai de Jaslykow Chelmensis dioecesis de licencia sui ordinarii ad provisionem venerabilis dominum Joannis Lathalski Gnesnensem Metropolitanem Cracoviensis et Lanciciensem ecclesiarum prepositi

k. 20v

Frater Gregorius de Przemislia ordinis fratrum minorum Sancti Francisci de observancia de licencia sui superioris

Stanislaus Nicolai de Paczonow Cracoviensis dioecesis de licencia sui ordinarii ad provisionem honorabilis plebani in Maiori Rudno et heredis de Pruschyn ${ }^{52}$

Nicolaus Joannis de Byszkupycze Cracoviensis dioecesis de licencia sui ordinarii ad provisionem domini Stanislai Kuropathwa castellani Chelmensis

Dominicus Jacobi de Korithnycza Cracoviensis dioecesis de licencia sui ordinarii ad provisionem nobilis domini Joannis Krupka heredis in Korithnycza

Nicolaus Nicolai de Przytyk Cracoviensis dioecesis de licencia sui ordinarii ad provisionem nobilis domini Jacobi Chamyecz heredis de Potok

\section{Ad gradum accolitatus}

Mathias Petri de Pyaszecznavola Posnanensis dioecesis de licencia sui ordinarii

Joannes Laurenty de Ostralanka ${ }^{53}$ Posnanensis dioecesis de licencia sui ordinarii

Andreas Joannis de Ropczycze Cracoviensis dioecesis de licencia domini loci ordinarii

Joannes Joannis de Lublyn de licencia generali domini loci ordinariii ${ }^{54}$

Joannes Jacobi de Branycza Cracoviensis dioecesis de licencia generali domini loci ordinarii

Joannes Fredrich de Lublyn Cracoviensis dioecesis de licencia generali domini loci ordinarii

\footnotetext{
${ }^{50}$ Jest to jedyny przypadek spośród wyświęconych w Lublinie, kiedy kandydat posiadał własny majątek, zapewniający mu utrzymanie.

${ }^{51}$ Por. przypis nr 47. Jeden z Mikołajów, piszący się „z Inowłodza” był wiceprepozytem katedralnym przemyskim.

${ }^{52} \mathrm{O}$ działach rodzinnych Pruszyńskich z Wielkiego Rudna. Kuraś, Stownik, s. 204.

${ }^{53}$ Starołęka w diecezji poznańskiej.

${ }^{54}$ Wpisany dwa razy, może jest to pomyłka pisarza, albo było dwóch kandydatów z Lublina o imieniu Jan s. Jana.
} 
Jacobus Mathiae de Kraszyenin Cracoviensis dioecesis de licencia generali domini loci ordinarii

Joannes Jacobi de Cazymyrz Cracoviensis dioecesis de licencia generali domini loci ordinarii

k. 21

Johannes Stanislai de Lublyn Cracoviensis dioecesis de licencia generali domini loci ordinarii

Jacobus Joannis de Byalka ${ }^{55}$ Cracoviensis dioecesis de licencia loci ordinarii

Joannes Joannis de Luchow Cracoviensis dioecesis de licencia loci ordinarii

Joannes Nicolai de Zwolyn Cracoviensis dioecesis de licencia loci ordinarii

Andreas Joannis de Posnan Posnanensis dioecesis de licencia sui ordinarii

Jacobus Martini de Sokal Chelmensis dioecesis de licencia sui ordinarii

Andreas Joannis de Nyezabythow Cracoviensis dioecesis de licencia sui ordinarii

Mathias Andree de Klymunthowycze Cracoviensis dioecesis de licencia sui ordinarii

Dobeslaus Stanislai de Przethoczno Cracoviensis dioecesis de licencia sui ordinarii

Jacobus Joannis de Lublyn Cracoviensis dioecesis de licencia sui ordinarii

Mathias Przybyslai de Koprzywyenszkavola Posnanensis dioecesis de licencia sui loci ordinarii

Petrus Petri de Komaschycze Cracoviensis dioecesis de licencia sui ordinarii

Petrus Joannis de Kazymyerz Cracoviensis dioecesis de licencia sui loci ordinarii

Adam Stanislai de Lublyn Cracoviensis dioecesis de licencia sui ordinarii

Martinus Stanislai de Kazymyrz Cracoviensis dioecesis de licencia sui loci ordinarii

Jacobus Stanislai de Kyszkow ${ }^{56}$ Gnesnensis dioecesis de licencia sui ordinarii

Nicolaus Ade de Wylky Posnanensis dioecesis de licencia sui ordinarii

Valentinus Nicolai de Ryky Cracoviensis dioecesis de licencia sui ordinarii

Petrus Nicolai de Szyczyna Cracoviensis dioecesis de licencia sui loci ordinarii

Nicolaus Joannis de Kobilanyow Cracoviensis dioecesis de licencia sui loci ordinarii

Frater Mathias de monasterio Lublynensis ordinis fratrum predicatorum de licencia sui superioris

Frater Nicolaus de eodem monasterio ordini predicatorum de licencia sui superioris

Stanislaus Mathie de Belzycze ${ }^{57}$ Cracoviensis dioecesis de licencia sui ordinarii

Gregorius Alberti de Curow dioecesis Cracoviensis de licencia sui ordinarii

Johannes Augustini de Cazymyrz Cracoviensis dioecesis de licencia sui dioecesani

Felix Joannis de Curow Cracoviensis dioecesis de licencia sui ordinarii

${ }^{55} \mathrm{~W}$ aktach oficjała lubelskiego zachował się interesująca umowa zawarta 29 III 1489 roku między Janem, plebanem w Białce oraz braćmi, Piotrem i Witem Górskimi, kolatorami i patronami tamże. W umowie zapisano, że w przypadku, gdyby pleban zechciał opuścić parafię musi zostawić następcy: 6 kop zboża, 2 woły, krowę z cielęciem, maciorę z prosiętami, 1 owcę, 2 gęsi, koguta i kury. Bliżej nieokreślone mobilia mógł zabrać ze sobą, AAL, ACL, sygn. Rep 60 A 5, k. 209.

${ }^{56}$ Nie był to pierwszy duchowny z Kiszkowa w diecezji gnieźnieńskiej w Lublinie. W 1460 roku niejaki Jan z Kiszkowa, prezentowany na altarię św. Barbary w kościele św. Michała, występował przeciw Annie, żonie rajcy lubelskiego Marka, o trzy grzywny, AAL, ACL, sygn. Rep 60 A 2, k. 198.

${ }^{57}$ Stanisław z Bełżyc był od 1525 roku wicedziekanem kapituły katedralnej przemyskiej. Po śmierci Jana z Pruchnika (1531) pełnił funkcję prepozyta szpitala św. Ducha w Przemyślu. Łosowska, Pennae, s. 257. 
Stanislaus Mathiae de Kazymyrz Cracoviensis dioecesis de licencia sui ordinarii Laurentius Nicolai de Wanwalnycza ${ }^{58}$ Cracoviensis dioecesis de licencia sui ordinarii Stanislaus Nicolai de Coninszkawola Cracoviensis dioecesis de licencia sui dioecesani Andreas Stanislai de Curow ${ }^{59}$ Cracoviensis dioecesis de licencia sui ordinarii Bartholomeus Andree de Ostroczernye ${ }^{60}$ Cracoviensis dioecesis de licencia sui ordinarii Mathias Jacobi de Zabczycze Cracoviensis dioecesis de licencia sui ordinarii Frater Stanislaus ordinis sancti Benedicti de Szyeczyechow de licencia sui superioris

\title{
CLERGYMEN ORDAINED IN LUBLIN BY PRZEMYŚL BISHOP MACIEJ DRZEWICKI
} (28 II 1506)

\begin{abstract}
Summary
This article demonstrates the list of seventy-three clergymen who were ordained by Przemyśl Bishop Maciej Drzewicki in Lublin in 1506. The majority of the ordained came from the area of Lublin Archdeaconry and this is the first publication of that documentary proof that has been unrecognised in literature so far. The list has survived in the books of Przemyśl bishops, which means that in similar documentary proofs various pieces of information extending beyond the boundaries of one diocese may be found.

It has been confirmed that the procedure of ordaining and preparatory activities for clerics to be set up for this celebration (examinations) were typical for all dioceses regardless of their location. In the field of granting commission, the secular patronage prevailed to be mainly represented by local noble families. The lists of the ordained, among whom also the clergymen from various dioceses may be found, is comparable to the research on distribution of the lower clergy in the territory of the Republic of Poland.
\end{abstract}

Translated by Monika Zielińska-Choina

${ }^{58}$ W 1495 roku Wawrzyniec z Wąwolnicy występował jeszcze jako uczeń. Chachaj, Bliżej schizmatyków niż Krakowa, s. 392.

${ }^{59}$ Andrzej z Kurowa jeszcze w 1511 roku występował jako ministerialis w Kurowie, zapewne więc nie uzyskał święceń wyższych. Chachaj, Bliżej schizmatyków niż Krakowa, s. 349.

${ }^{60} \mathrm{Nie}$ zidentyfikowano miejscowości. 